\title{
Effect of salicylic acid and progesterone on physiological characteristics of Kentucky bluegrass under salinity stress
}

\author{
Efecto del ácido salicílico y la progesterona en las características fisiológicas \\ del Kentucky bluegrass bajo estrés por salinidad
}

Elham Sabzmeydani $^{1}$; Shahram Sedaghathoor ${ }^{2}$; Davood Hashemabadi ${ }^{3}$

\begin{abstract}
ARTICLE DATA
1. Ph.D. Islamic Azad University, Rasht Branch, Rasht, Iran.elham.sabzmeydani@yahoo.co

2. Associate Professor, Ph.D. Department of Horticulture, Islamic Azad University, Rasht Branch, Rasht, Iran, sedaghathoor@yahoo.com

3. Associate Professor, Department of Horticulture, Islamic Azad University, Rasht Branch, Rasht, Iran, davoodhashemabadi@yahoo.com
\end{abstract}

Cite:Sabzmeydani, E.; Sedaghathoor, S.; Hashemabadi, D. (2021). Effect of salicylic acid and progesterone on physiological characteristics of Kentucky bluegrass under salinity stress. Revista de Ciencias Agrícolas. 38(1):111-124.

doi: https://doi.org/10.22267/rcia.213801.151

Received: Jun 052021.

Accepted: April 302021.

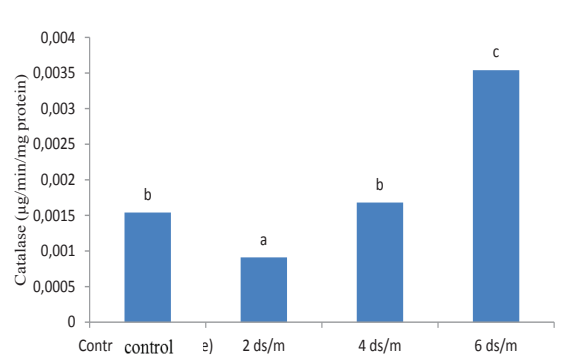

The effect of different levels of salinity stress on catalase of Kentucky bluegrass.

\section{ABSTRACT}

Salinity is one of the most important limiting factors in plant growth. It is also a predominant constraint that impairs grass growth and quality. Plant hormones play important roles in the capability of plants to adapt to environmental stresses. Hence, the impact of two plant growth regulators (PGRs) i.e. salicylic acid (SA) and progesterone (P4) was studied on biological characteristics of Poa pratensis in saline conditions in a greenhouse experiment. The experimental treatments were composed of salinity at four levels $\left(0,2,4\right.$, and $\left.6 \mathrm{dS} \mathrm{m}^{-1}\right)$ and six levels of PGRs (control, $1 \mathrm{mg} \mathrm{L}^{-1} \mathrm{P} 4,10 \mathrm{mg} \mathrm{L}^{-1} \mathrm{P} 4,1 \mathrm{mM} \mathrm{SA}, 3 \mathrm{mM} \mathrm{SA}$, and $1 \mathrm{mg} \mathrm{L}^{-1} \mathrm{P} 4+$ $1 \mathrm{mM} \mathrm{SA}$ ). The results showed that leaf firing percentage was increased with the excess in salinity, but the use of SA and P4 eased the effects of salinity stress and reduced leaf firing under salinity. $6 \mathrm{dS} \mathrm{m}^{-1}$ and 3 $\mathrm{mM}$ SA salinity caused to the maximum electrolyte leakage. The highest relative water content was observed in $4 \mathrm{dS} \mathrm{m}^{-1}$ salinity and $1 \mathrm{mM} \mathrm{SA}$ treatment. The highest glycine betaine was related to $6 \mathrm{dS} \mathrm{m}^{-1} \mathrm{NaCl}$ and no hormone application. Salinity increased total protein and catalase, and the simultaneous use of P4 and SA exhibited the highest total protein and catalase content, whilst the control plants showed the lowest ones. The application of salinity stress reduced chlorophyll content, but SA and P4 increased it. The application of the two growth regulators improved carotenoid content under salinity stress. Overall, the results showed that the application of SA and P4 improved salinity tolerance and increased pigments and antioxidant enzyme activities.

Keywords: lawn; ascorbate peroxidase; reactive oxygen; carotenoid.

\section{RESUMEN}

La salinidad es uno de los factores limitantes más importantes en el crecimiento de las plantas. También es una limitación predominante que afecta el crecimiento y la calidad del césped. Las hormonas vegetales desempeñan un papel importante en la capacidad de las plantas para adaptarse al estrés ambiental. Por lo tanto, se estudió el impacto 
de dos reguladores del crecimiento de las plantas (PGR), es decir, el ácido salicílico (SA) y la progesterona (P4), sobre las características biológicas de Poa pratensis en condiciones salinas en un experimento de invernadero. Los tratamientos experimentales estaban compuestos por salinidad en cuatro niveles $\left(0,2,4 \mathrm{y} \mathrm{dS} \mathrm{m}^{-1}\right)$ y seis niveles de PGRs (control, $1 \mathrm{mg} \mathrm{L}^{-1} \mathrm{P} 4,10 \mathrm{mg} \mathrm{L}^{-1} \mathrm{P} 4,1 \mathrm{mM} \mathrm{SA}, 3 \mathrm{mM}$ SA y $1 \mathrm{mg} \mathrm{L}^{-1} \mathrm{P} 4+1 \mathrm{mM} \mathrm{SA}$ ). Los resultados mostraron que el porcentaje de disparo de las hojas se incrementó con el exceso de salinidad, pero el uso de SA y P4 alivió los efectos del estrés por salinidad y redujo el disparo de las hojas bajo salinidad. La salinidad de $6 \mathrm{dS} \mathrm{m}^{-1}$ y $3 \mathrm{mM}$ de SA provocó la máxima fuga de electrolitos. El mayor contenido relativo de agua se observó en el tratamiento de $4 \mathrm{dS}$ m-1 de salinidad y $1 \mathrm{mM}$ de SA. La mayor glicina betaína se relacionó con $6 \mathrm{dS} \mathrm{m}{ }^{-1} \mathrm{de} \mathrm{NaCl}$ y sin aplicación de hormonas. La salinidad aumentó la proteína total y la catalasa, y el uso simultáneo de P4 y SA mostró el mayor contenido de proteína total y catalasa, mientras que las plantas control mostraron los más bajos. La aplicación de estrés por salinidad redujo el contenido de clorofila, pero la SA y el P4 lo aumentaron. La aplicación de los dos reguladores de crecimiento mejoró el contenido de carotenoides bajo estrés por salinidad. En general, los resultados mostraron que la aplicación de SA y P4 mejoró la tolerancia a la salinidad y aumentó los pigmentos y las actividades de las enzimas antioxidantes.

Palabras clave: césped; ascorbato peroxidasa; oxígeno reactivo; carotenoides

\section{INTRODUCTION}

Grass, an ornamental plant for open spaces with a long history of application, still has its special importance in the design of green spaces. Grasses have different species, some of them very important in pasture or other applications (Souri and Neumann, 2018). The ornamental grasses have originated from the palaces of Persian kings in the first millennium B.C. (Koch et al., 2011). With the development of urbanization, grasses emerged as an integrated part of people's living environment and gained importance from the perspective of environmental improvement, their decorative, recreational, sporting role, and their role in satisfying mental and emotional needs (Adavi et al., 2006). Salinity is one of the most important environmental stress that can significantly reduce plant growth and agricultural production (Ahmadi and Souri, 2018; Ahmadi and Souri, 2020). It is also a major constraint of the grass industry as it impairs grass quality (Moghadamyar et al., 2019). As salinity grows in many parts of the world, so does the role of grasses in landescaping and environemntal planings, which will face problems (Souri and Hatamian, 2019). Some thechniques such as application of PGRs can lighten the injuries of this stress by inducing stress resistance. Plant growth regulators, e.g. salicylic acid (SA), can be used as a short-term solution for reducing the negative impacts of various stresses (Souri and Tohidloo, 2019). SA is an endogenous PGR from the group of naturally occurring phenol compounds and involves the adjustment of plant activities (Waseem et al., 2006).

Multiple studies have found that SA has a positive impact on a wide range of traits including seed germination, growth, yield, yield components, physiology, and biochemistry of plants, especially in saline conditions (Ashraf et al., 2010; Souri and Tohidloo, 2019). Mammalian sex hormones (MSH), such as progesterone, are a group of steroids that play an important duty in regulatory plant growth processes as well as the metabolism of minerals and proteins in mammals (Erdal and Dumlupinar, 2011). Steroid sex hormones, e.g. progesterone, improve growth, cell division, and pollination of plants; additionally, they help to cope with salinity (Rojek et al., 2015; Genisel et al., 2013; Metwally et al., 2015). Xue et al. (2017) reported that the application of 
progesterone under stressful conditions alleviated the impacts of oxidative stress, increased catalase, and reduced leaf proteins of wheat as compared to the plants subject to the stress but not treated with the hormone. Arghavani et al. (2017) also reported that salinity stress reduced the chlorophyll content and apparent quality of Poa grass. However, Yang et al. (2014) revealed that the irrigation of golf course grass or creeping bentgrass (Agrostisstolonifera L.) with salt water reduced turf quality, shoot growth rate, catalase, leaf relative water content, and total chlorophyll content versus the control. Zhang (2016) found that salinity stress reduced the quality traits of grass and catalase activity whereas salinity-exposed bentgrass sprayed with SA enhanced the traits that had been reduced under stress conditions.

Given the special place of Poa grass in green spaces and the reportedly positive impact of salicylic acid (SA) and progesterone (P4) on injuries of salinity stress, the investigation aimed to take a more precise look at the salinity tolerance of this plant species, their physiological and biochemical responses to salinity conditions, and the application of SA and P4.

\section{MATERIALS AND METHODS}

The study was conducted in a glasshouse (average day/night temperature of $25^{\circ} \mathrm{C}$, photoperiod of 16 hours, photosynthetically active radiation of $1470 \pm 11 \mathrm{u} \mathrm{mol} \mathrm{m}^{-2} \mathrm{~s}^{-1}$, and RH of 50\%) in Chaharbagh in Karaj, Iran in 2017-2018 as a factorial experiment based on a RCBD with 4 replications. The experimental treatments included 4 levels of salinity $(0,2$, 4 , and $6 \mathrm{dS} \mathrm{m}^{-1}$ ) and 6 treatments obtained from two PGRs (control, $1 \mathrm{mg} \mathrm{L}^{-1} \mathrm{P} 4,10 \mathrm{mg} \mathrm{L}^{-1}$ P4, $1 \mathrm{mM} \mathrm{SA}, 3 \mathrm{mM} \mathrm{SA}$, and $1 \mathrm{mg} \mathrm{L}^{-1} \mathrm{P} 4+1$
mM SA). The seeds of Kentucky bluegrass, which were already procured from IranBazr Company, were sown in plastic pots with a mouth diameter of $25 \mathrm{~cm}$ and a height of 35 $\mathrm{cm}$. The substrate was composed of $49 \%$ sand, $12 \%$ clay, and $39 \%$ silt. The EC of the water in the control plants was 1200 $\mu$ mho $\mathrm{cm}^{-1}$. Two months after seeding and using freshwater, salinity was used in a 40 day period. The SA and P4 treatments were applied in 3 stages ( 2 weeks earlier salinity begins, 2 weeks later stress begins, and 4 weeks later salinity begins).

Leaf firing percentage was visually measured from 0 to 100. Plant height was measured with a ruler which was placed in three spots of the pots before turfgrass mowing (weeks 2 and 5 after salinity stress initiation) and the mean height of the canopy was recorded. Chlorophyll content and carotenoids were measured by Arnof's (1946) method. Absorbance was read with a microplate reader (ELX808, Bio Teck, US) at 663, 645 and $470 \mathrm{~nm}$.

Carotenoid $=\frac{100 \mathrm{~A}_{470}-3.27 \mathrm{mg} \mathrm{chl} . \mathrm{a}-104 \mathrm{mg} \text { chl.b }}{227}$

Total chlorophyll content $=2.20 \times \mathrm{A}_{470}-8.20 \times \mathrm{A}_{663} \times \mathrm{V} / 100 \mathrm{~W}$

$\mathrm{V}=$ the volume of infiltrated solution (the supernatant after centrifuging)

$\mathrm{A}=$ absorbance at 663,645 and $470 \mathrm{~nm}$

$\mathrm{W}=$ sample fresh weight in $\mathrm{g}$

Glycine betaine content in terms of the complicated betaine-peridotite composition was measured by Grieve and Grattan's (1983) method with some slight modifications. Total protein content of the samples was determined using Bradford's (1976) method, for which a spectphotometer was used. The method described by Aebi (1984) was used to 
determine catalase, and Bates et al.'s (1973) method was applied to find out proline content. To measure relative water content, leaf samples at an approximate size of $1 \mathrm{~cm}$ were randomly taken from each pot. Then, their fresh weight (FW) was immediately determined. Next, the samples were floated in Petri dishes with a lid filled with distilled water at room conditions and low light intensity for 3 hours. The samples were then taken out of the distilled water; their surface was gently dried with a tissue, and their saturated weight (SW) was immediately recorded. Afterward, they were oven-dried at $72^{\circ} \mathrm{C}$ for 24 hours to find out their dry weight (DW). Finally, relative water content was determined by the following equation:

$$
\text { Relative water content }(\%)=\frac{F W-D W}{S W-D W} \times 100
$$

Data were analyzed by the SAS Software Package (v. 9.3 for Window; SAS Institute, Cary, NC, United States, 2010). Means were compared by the Tukey method (HSD) at the $P<0.05$ level.

\section{RESULTS AND DISCUSSION}

Grass leaf firing. In the first week after the treatment application, no leaf firing was observed. Also, the analysis of variance (ANOVA) for leaf firing indicated that the simple effect of salinity, SA and P4 and their interactive effects were significant on leaf firing at all measurement times (except for the effect of the hormone in the second week) (Table 1).

The comparison of the means for the interactions revealed that no firing was observed in the treatments in the first week, but it had an ascending trend over time and with the increase in salinity stress. However, the application of different hormones reduced it. In the control treatments, salinity stress had the lowerst leaf firing of $0 \%$, and the highest was in the treatments of $6 \mathrm{dS} \mathrm{m} \mathrm{m}^{-1}$ and no hormone treatment. In addition, when salinity stress increased, the positive effects of the hormones on firing percentage became more apparent and reduced leaf firing in the grass (Table 2).

Tajmirriahi et al. (2015) reported that leaf firing percentage increased along with salinity concentration so that the highest was observed at salinity levels of 8 and 16 $\mathrm{dS} \mathrm{m}^{-1}$. Alshammary et al. (2004) found that leaf firing percentage was lower in tall fescue grass than in Kentucky bluegrass at a salinity level of $9.4 \mathrm{dS} \mathrm{m}^{-1}$.

Table 1. The results of ANOVA for the leaf firing of Poa pratensis in different weeks.

\begin{tabular}{lrlllllll}
\hline \multirow{2}{*}{$\begin{array}{c}\text { Sources of } \\
\text { variation }\end{array}$} & df & \multicolumn{7}{c}{ MS } \\
\cline { 3 - 8 } & & Week 1 & Week 2 & Week 3 & Week 4 & Week 5 & Week 6 & Week 7 \\
\hline Replication & 3 & 0.00 & $0.003^{\text {ns }}$ & $3.12^{* *}$ & $8.04^{* *}$ & $22.06^{*}$ & $14.40^{\text {ns }}$ & $111.24^{* *}$ \\
Salinity (A) & 3 & 0.00 & $106.26^{* *}$ & $1102.04^{* *}$ & $1923.54^{* *}$ & $4533.29^{* *}$ & $7370.13^{* *}$ & $10106.24^{* *}$ \\
Hormone (B) & 5 & 0.00 & $0.16^{*}$ & $8.79^{* *}$ & $34.17^{* *}$ & $63.27^{* *}$ & $111.20^{* *}$ & $124.38^{* *}$ \\
AB & 15 & 0.00 & $0.17^{* *}$ & $3.46^{* *}$ & $6.21^{* *}$ & $14.71^{*}$ & $27.52^{*}$ & $41.17^{*}$ \\
Error & 69 & 0.00 & 0.090 & 0.60 & 1.89 & 7.47 & 15.58 & 22.61 \\
CV (\%) & & 0.00 & 28.58 & 17.18 & 17.13 & 19.65 & 19.20 & 17.49 \\
\hline
\end{tabular}

*: significant at the $\mathrm{P}<0.05$ level; ${ }^{* *}$ : significant at the $\mathrm{P}<0.01$ level; ns: non-significant 
Table 2. The comparison of means for the interactive effect of salinity and hormone on leaf firing of grass in different weeks.

\begin{tabular}{|c|c|c|c|c|c|c|c|c|}
\hline Salinity stress & Hormones & Week 1 & Week 2 & Week 3 & Week 4 & Week 5 & Week 6 & Week 7 \\
\hline \multirow[t]{6}{*}{ Control } & Control (no hormone) & 0.00 & $0.00 \mathrm{~d}$ & $0.00 \mathrm{~h}$ & $0.00 \mathrm{j}$ & $0.00 \mathrm{j}$ & $0.00 \mathrm{j}$ & $0.00 \mathrm{~h}$ \\
\hline & $1 \mathrm{mg} \mathrm{L}^{-1}$ progesterone & 0.00 & $0.00 \mathrm{~d}$ & $0.00 \mathrm{~h}$ & $0.00 \mathrm{j}$ & $0.00 \mathrm{j}$ & $0.00 \mathrm{j}$ & $0.00 \mathrm{~h}$ \\
\hline & $10 \mathrm{mg} \mathrm{L}^{-1}$ progesterone & 0.00 & $0.00 \mathrm{~d}$ & $0.00 \mathrm{~h}$ & $0.00 \mathrm{j}$ & $0.00 \mathrm{j}$ & $0.00 \mathrm{j}$ & $0.00 \mathrm{~h}$ \\
\hline & $1 \mathrm{mM}$ salicylic acid & 0.00 & $0.00 \mathrm{~d}$ & $0.00 \mathrm{~h}$ & $0.00 \mathrm{j}$ & $0.00 \mathrm{j}$ & $0.00 \mathrm{j}$ & $0.00 \mathrm{~h}$ \\
\hline & 3 mM salicylic acid & 0.00 & $0.00 \mathrm{~d}$ & $0.00 \mathrm{~h}$ & $0.00 \mathrm{j}$ & $0.00 \mathrm{j}$ & $0.00 \mathrm{j}$ & $0.00 \mathrm{~h}$ \\
\hline & Progesterone + salicylic acid & 0.00 & $0.00 \mathrm{~d}$ & $0.00 \mathrm{~h}$ & $0.00 \mathrm{j}$ & $0.00 \mathrm{j}$ & $0.00 \mathrm{j}$ & $0.00 \mathrm{~h}$ \\
\hline \multirow{6}{*}{$2 \mathrm{dS} \mathrm{m}^{-1}$ salinity } & Control (no hormone) & 0.00 & $0.00 \mathrm{~d}$ & $0.00 \mathrm{~h}$ & $5.50 \mathrm{f}-\mathrm{h}$ & 10.00gh & $18.00 \mathrm{f}-\mathrm{h}$ & $28.75 \mathrm{~d}-\mathrm{f}$ \\
\hline & $1 \mathrm{mg} \mathrm{L}^{-1}$ progesterone & 0.00 & $0.00 \mathrm{~d}$ & $0.00 \mathrm{~h}$ & $4.50 \mathrm{~g}-\mathrm{j}$ & $8.75 g-i$ & 17.50f-h & $27.00 \mathrm{ed}$ \\
\hline & $10 \mathrm{mg} \mathrm{L}^{-1}$ progesterone & 0.00 & $0.00 \mathrm{~d}$ & $0.00 \mathrm{~h}$ & $4.00 \mathrm{~g}-\mathrm{j}$ & $8.25 \mathrm{~g}-\mathrm{i}$ & $17.00 \mathrm{f}-\mathrm{h}$ & $27.00 \mathrm{ef}$ \\
\hline & $1 \mathrm{mM}$ salicylic acid & 0.00 & $0.00 \mathrm{~d}$ & $0.00 \mathrm{~h}$ & 3.50hi & 8.00hi & $16.00 \mathrm{gh}$ & $27.50 \mathrm{ef}$ \\
\hline & $3 \mathrm{mM}$ salicylic acid & 0.00 & $0.00 \mathrm{~d}$ & $0.00 \mathrm{~h}$ & $3.00 \mathrm{~h}-\mathrm{j}$ & 7.00hi & 14.50hi & $23.00 \mathrm{fg}$ \\
\hline & Progesterone + salicylic acid & 0.00 & $0.00 \mathrm{~d}$ & $0.00 \mathrm{~h}$ & $2.00 \mathrm{ij}$ & $5.00 \mathrm{i}$ & $10.00 \mathrm{i}$ & $20.00 \mathrm{~g}$ \\
\hline \multirow{6}{*}{$4 \mathrm{dS} \mathrm{m}^{-1}$ salinity } & Control (no hormone) & 0.00 & $0.00 \mathrm{~d}$ & $5.50 \mathrm{~d}$ & $10.00 \mathrm{~d}$ & $20.00 \mathrm{~d}$ & $30.25 \mathrm{~cd}$ & $40.00 c$ \\
\hline & $1 \mathrm{mg} \mathrm{L}^{-1}$ progesterone & 0.00 & $0.00 \mathrm{~d}$ & $4.50 \mathrm{de}$ & $8.75 \mathrm{~d}$ & 17.00de & 26.00de & $35.00 \mathrm{bcd}$ \\
\hline & $10 \mathrm{mg} \mathrm{L}^{-1}$ progesterone & 0.00 & $0.00 \mathrm{~d}$ & 4.00de & $8.25 \mathrm{de}$ & $16.00 \mathrm{e}$ & 26.00de & $35.00 \mathrm{~cd}$ \\
\hline & $1 \mathrm{mM}$ salicylic acid & 0.00 & $0.00 \mathrm{~d}$ & $3.50 \mathrm{ef}$ & $7.75 \mathrm{~d}-\mathrm{f}$ & $14.75 \mathrm{ef}$ & $24.00 \mathrm{e}$ & 33.00de \\
\hline & $3 \mathrm{mM}$ salicylic acid & 0.00 & $0.00 \mathrm{~d}$ & $3.00 \mathrm{fg}$ & 7.00d-g & $14.00 \mathrm{ef}$ & $22.00 \mathrm{ef}$ & 33.00de \\
\hline & Progesterone + salicylic acid & 0.00 & $0.00 \mathrm{~d}$ & $2.00 \mathrm{~g}$ & $5.00 \mathrm{f}-\mathrm{i}$ & $12.00 \mathrm{fg}$ & $21.00 \mathrm{~d}-\mathrm{f}$ & 30.00de \\
\hline \multirow{6}{*}{$6 \mathrm{dS} \mathrm{m}^{-1}$ salinity } & Control (no hormone) & 0.00 & $4.50 \mathrm{a}$ & $17.75 \mathrm{a}$ & $25.00 \mathrm{a}$ & $36.00 \mathrm{a}$ & $47.00 \mathrm{a}$ & $54.75 a$ \\
\hline & $1 \mathrm{mg} \mathrm{L}^{-1}$ progesterone & 0.00 & $4.00 \mathrm{~b}$ & $14.25 b$ & $22.00 \mathrm{ab}$ & $34.00 \mathrm{ab}$ & $44.50 \mathrm{ab}$ & $50.00 \mathrm{ab}$ \\
\hline & $10 \mathrm{mg} \mathrm{L}^{-1}$ progesterone & 0.00 & $4.50 \mathrm{a}$ & $14.00 \mathrm{~b}$ & $21.00 \mathrm{~b}$ & $33.00 \mathrm{ab}$ & $43.00 \mathrm{ab}$ & $51.00 \mathrm{ab}$ \\
\hline & $1 \mathrm{mM}$ salicylic acid & 0.00 & $4.25 \mathrm{ab}$ & $14.00 \mathrm{~b}$ & $19.50 \mathrm{~b}$ & $32.00 \mathrm{~b}$ & $43.00 \mathrm{ab}$ & $49.50 \mathrm{ab}$ \\
\hline & $3 \mathrm{mM}$ salicylic acid & 0.00 & $4.50 \mathrm{a}$ & $13.75 b$ & $20.00 \mathrm{~b}$ & $33.00 \mathrm{ab}$ & $40.00 \mathrm{~b}$ & $48.00 \mathrm{~b}$ \\
\hline & Progesterone + salicylic acid & 0.00 & $3.50 \mathrm{c}$ & $12.25 c$ & $16.00 \mathrm{c}$ & $25.00 c$ & $33.75 c$ & $40.00 \mathrm{c}$ \\
\hline
\end{tabular}

Means with similar letter(s) in each column did not differ significantly (LSD 5\%).

Grass height. According to the results of ANOVA, plant height at both measurement steps was significantly affected by the simple effect of salinity stress $(\mathrm{P}<0.01)$ and the interactiveimpact of salinity and the hormones SA and P4 (P < 0.05). Also, the simple effect of $\mathrm{SA}$ and $\mathrm{P} 4$ in the second week was significant $(\mathrm{P}<0.01)$ on this trait (Table 3). The comparison of the means for the interaction of salinity and the hormones revealed that in the second week, the application of $3 \mathrm{mM}$ SA to no-stress conditions was related to the highest plant height and the plants exposed to $6 \mathrm{dS} \mathrm{m}^{-1}$ salinity; those not treated with the hormones exhibited the lowest plant height. In the fifth week, the no-stress treatment had the highest plant height regardless the hormone level. In contrast, the lowest was detected in the plants exposed to $6 \mathrm{dS} \mathrm{m}^{-1}$ and no hormone. At the control salinity level, the difference in height due to the hormone treatments was not significant. Conversely, as the salinity level increased, the positive effect of the hormones was remarkable on plant 
height (Table 4). In the study of Arghavani etal. (2017), the use of SA in saline circumstances partially compensated for plant height. It was reported that SA increased cell division inside wheat seedling meristem and improved plant growth (Agarwal et al., 2005).

Leaf relative water content. Based on the outcomes of ANOVA, the simple impact of SA and $\mathrm{P} 4$ and the interactive effect of salinity stress and hormones were significant on relative water content $(\mathrm{P}<0.05$; Table 3$)$. It was found from the comparison of the means for the interaction that the plants exposed to $4 \mathrm{dS} \mathrm{m}^{-1}$ salinity and treated with $1 \mathrm{mM} \mathrm{SA}$ had the highest relative water content although they did not differ from the plants exposed to some other treatments significantly. In general, the hormones and salinity could not change relative water content remarkably though there were slight differences among the treatments. The lowest relative water content was related to the interaction of 6 $\mathrm{dS} \mathrm{m}^{-1}$ salinity and $1 \mathrm{mM} \mathrm{SA}$ (Table 4). The loss of water potential hinders cell division, organ growth, net photosynthesis, and protein synthesis and changes hormone balance in key tissues of the plants. It has been well established that plants exposed to drought and salinity stress lose their relative water content, leaf water potential, and cell osmotic potential. The decline in relative water content is greater in sensitive species than in resistant species (Ma et al., 2007; Pettigrew, 2004). Idrees et al. (2010) attributed the desirable impact of SA on the increased growth of roots due to better water uptake under salinity stress, which supports our findings. Similarly, our results are consistent with the study of Soliman et al. (2018), in which relative water content decreased with the increase in salinity and exhibited a correlation of 0.89 with salinity resistance.

Glycine betaine. It was revealed by ANOVA that glycine betaine was significantly influenced by salinity stress, the hormones, and their interaction (Table 3). The highest glycine betaine content was obtained from the treatment of $6 \mathrm{dS} \mathrm{m}^{-1}$ salinity and no hormone application and the lowest from the interaction of the control salinity and the application of $1 \mathrm{mM} \mathrm{SA}+1 \mathrm{mg} \mathrm{L}^{-1} \mathrm{P} 4$. At all salinity levels, the simultaneous use of P4 and SA was related to the lowest mean glycine betaine (Table 4). These results imply the positive effect of these hormones on glycine betaine content, which rises in exposure to salinity. Yang et al. (2012) found that glycine betaine and SA increased in plant cells in stressful conditions. However, these two compounds seem to have a partially negative correlation.

Table 3. Analysis of variance for the impact of experimental treatments on the traits of Poa pratensis.

\begin{tabular}{|c|c|c|c|c|c|c|c|c|c|c|c|}
\hline \multirow{2}{*}{$\begin{array}{l}\text { Sources of } \\
\text { variation }\end{array}$} & \multirow[b]{2}{*}{$\mathrm{df}$} & \multicolumn{10}{|c|}{ MS } \\
\hline & & $\begin{array}{c}\text { Plant height } \\
\text { Week } 2\end{array}$ & $\begin{array}{l}\text { Plant height } \\
\text { Week } 5\end{array}$ & $\begin{array}{c}\text { Leaf } \\
\text { carotenoid }\end{array}$ & $\begin{array}{c}\text { Total } \\
\text { chlorophyll }\end{array}$ & $\begin{array}{c}\text { Leaf relative } \\
\text { water content }\end{array}$ & $\begin{array}{l}\text { Glycine } \\
\text { betaine }\end{array}$ & $\begin{array}{c}\text { Total } \\
\text { protein }\end{array}$ & Catalase & $\begin{array}{c}\text { Leaf } \\
\text { carotenoid }\end{array}$ & $\begin{array}{c}\text { Total } \\
\text { chlorophyll }\end{array}$ \\
\hline Replication & 3 & $0.38 \mathrm{~ns}$ & $0.22 \mathrm{~ns}$ & $0.004 \mathrm{~ns}$ & $0.140 \mathrm{~ns}$ & $72.42 \mathrm{~ns}$ & $0.58^{* *}$ & $0.32 \mathrm{~ns}$ & $8.65 n s$ & $0.004 \mathrm{~ns}$ & $0.140 \mathrm{~ns}$ \\
\hline Salinity (A) & 3 & $14.22^{* *}$ & $28.76^{* *}$ & $0.241^{* *}$ & $2.736^{* *}$ & $35.89 \mathrm{~ns}$ & $3.77^{* *}$ & $9.31^{* *}$ & $3.08^{* *}$ & $0.241^{* *}$ & $2.736^{* *}$ \\
\hline Hormone (B) & 5 & $0.46^{*}$ & $0.19 \mathrm{~ns}$ & $0.007 \mathrm{~ns}$ & $0.156^{*}$ & $107.86^{*}$ & $0.80^{* *}$ & $1.07 \mathrm{~ns}$ & $1.69^{* *}$ & $0.007 \mathrm{~ns}$ & $0.156^{*}$ \\
\hline $\mathrm{AB}$ & 15 & $0.53^{*}$ & $0.29 *$ & $0.010^{*}$ & $0.123^{*}$ & $71.79 *$ & $0.21^{*}$ & $0.37 \mathrm{~ns}$ & $6.58 \mathrm{~ns}$ & $0.010^{*}$ & $0.123^{*}$ \\
\hline Error & 69 & 0.23 & 0.16 & 0.005 & 0.066 & 38.61 & 0.11 & 0.48 & 3.64 & 0.005 & 0.066 \\
\hline CV (\%) & & 8.24 & 6.73 & 17.03 & 15.08 & 7.05 & 12.53 & 17.90 & 31.51 & 17.03 & 15.08 \\
\hline
\end{tabular}

*: significant at the $\mathrm{P}<0.05$ level; **: significant at the $\mathrm{P}<0.01$ level; ns: non-significant 


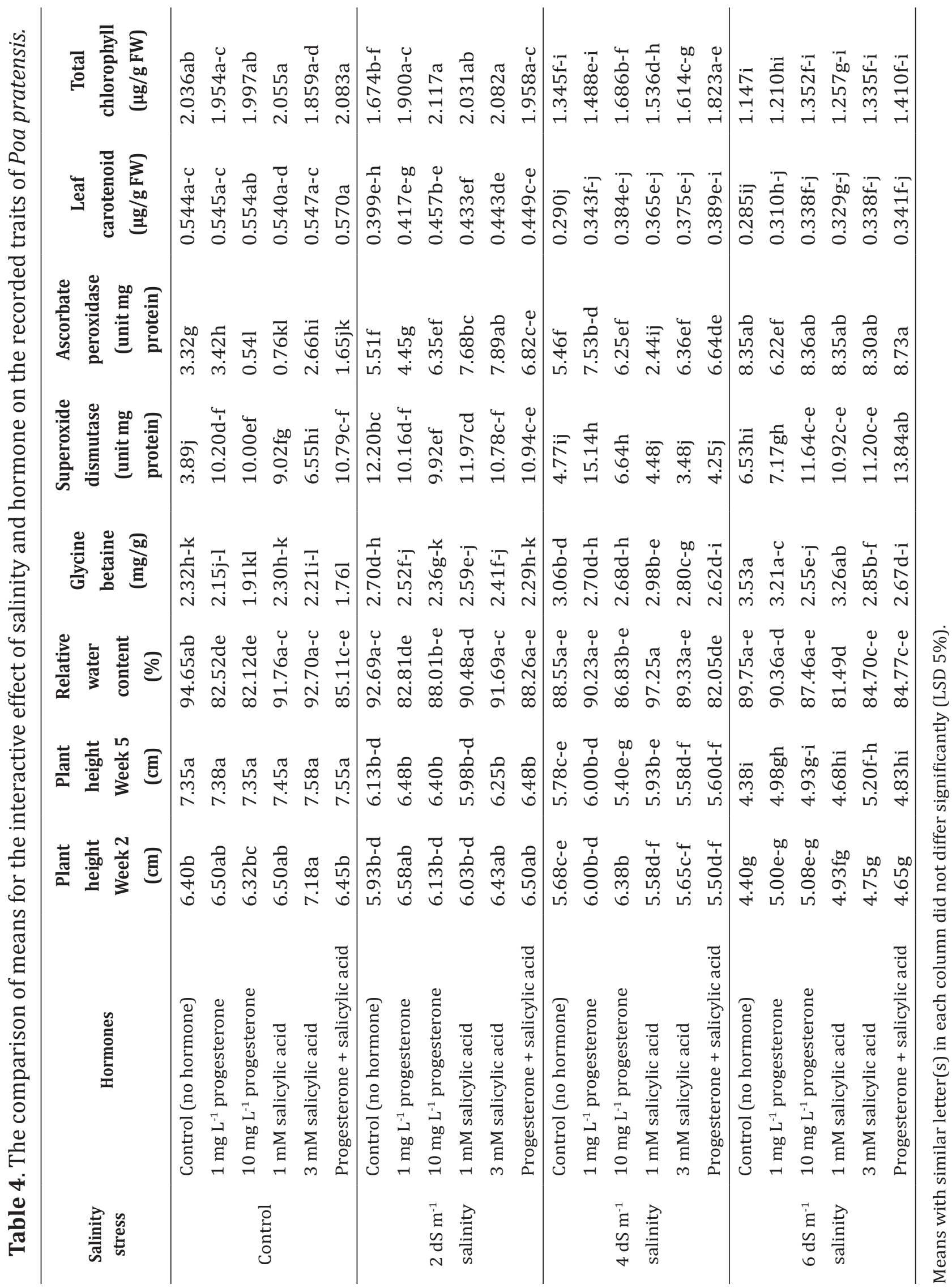


Total protein. The ANOVA test (F-test) revealed that the simple effect of the salinity stress and hormones was significant on total protein content at the $\mathrm{P}<0.01$ and $\mathrm{P}<0.05$ levels, respectively. However, their interaction was insignificant on protein content (Table 5). According to the comparison of the means for salinity levels, the control had the highest and the salinity level of $6 \mathrm{dS} \mathrm{m}^{-1}$ had the lowest total protein content (Figure 1). Accordingly, salinity had an ascending impact on total protein content. That is, the latter reduced with the rise in the salinity level. Application of P4 and SA together resulted in the highest total protein content. The control plants, not treated with the hormones, exhibited the lowest level of this trait (Figure 2).

The maintenance of effective proteins and the inhibition of the accumulation of ineffective proteins in stressful conditions are vital for cell survival. In mild stresses, total protein content may decline. But, in severe stresses, total protein content may increase due to the synthesis of new proteins called stress proteins (Demiral and Türkan, 2006). Salinity stress induces quantitative and qualitative changes in cell soluble proteins. Proteins that are accumulated in plants under salinity stress conditions may have a form of nitrogen reserve, which will be used by the plant subsequently or may be involved in osmotic adjustment.

They may also be re-used to synthesize osmotin-like proteins or structural proteins, or they may change cell wall structure. These proteins may be synthesized in response to salinity stress or may structurally exist in slight concentrations (Parvaiz and Satyawati, 2008). Manna et al. (2013) reported a decrease in plant soluble proteins with the increase in salinity. Padash et al. (2018) stated that SA using increased total protein of basil.

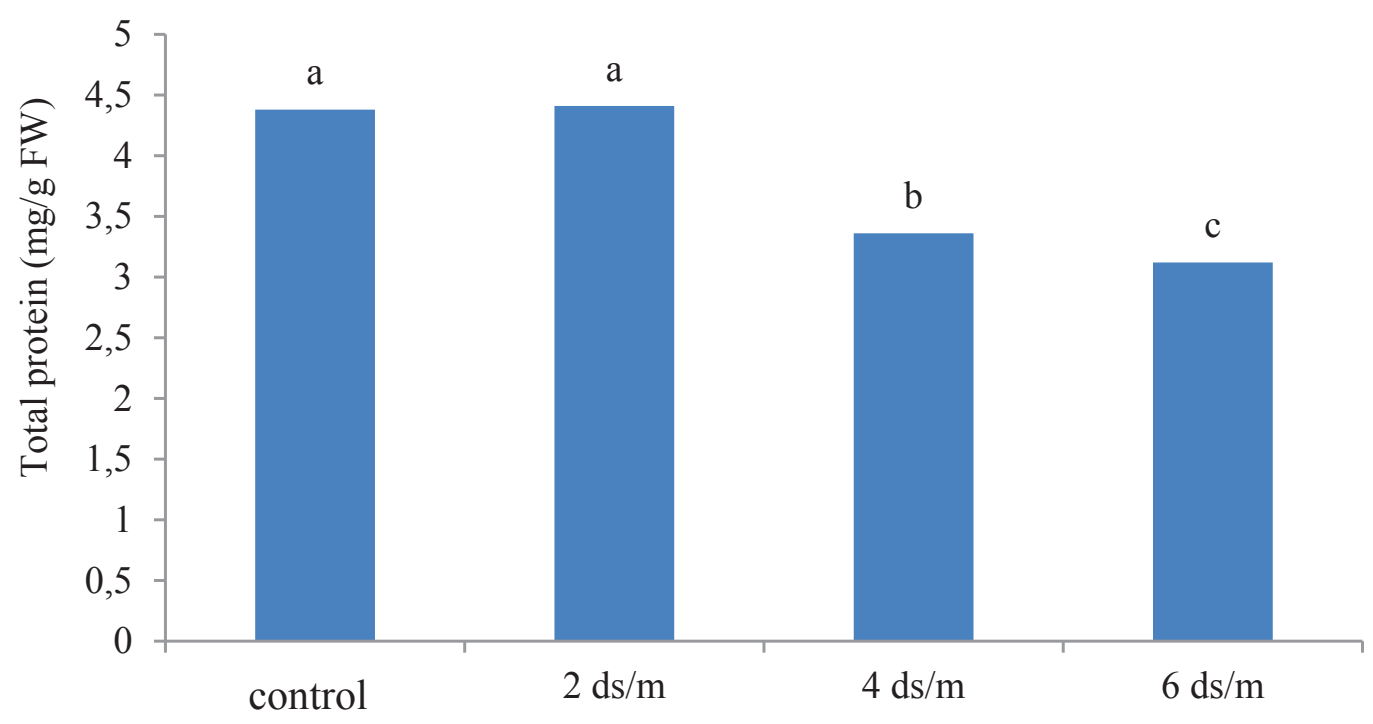

Figure 1. The effect of different levels of salinity stress on total protein of Kentucky bluegrass. 


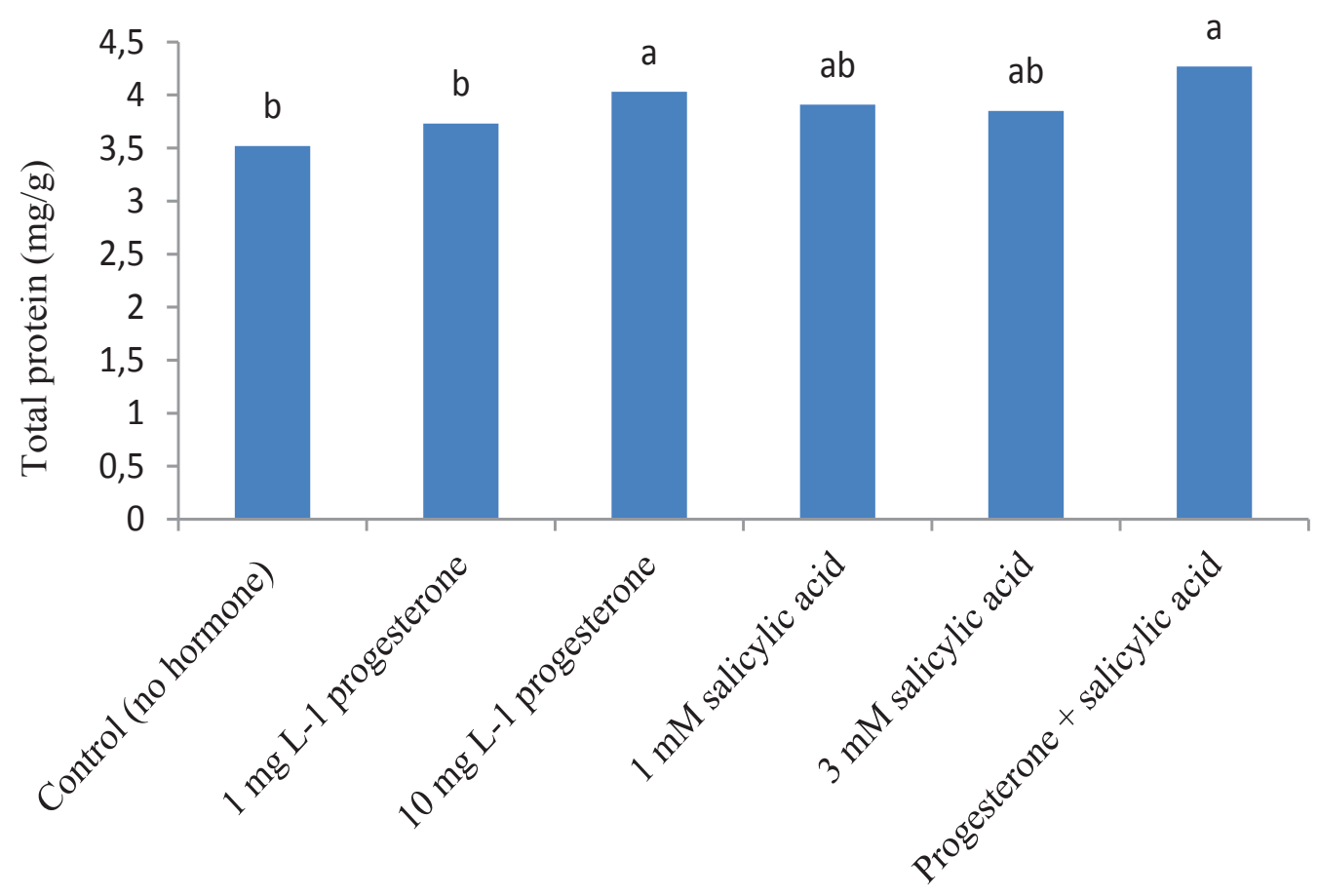

Figure 2. The impact of different concentration of progesterone and SA on total protein of Kentucky bluegrass.

Catalase activity. The results of the ANOVA indicated that the simple effect of salinity stress and hormones was significant $(\mathrm{P}<0.01)$ on catalase activity. But, the trait was not influenced by their interaction significantly (Table 3). Based on the comparison of the means for the effect of salinity stress, the control had the lowest catalase activity and $6 \mathrm{dS} \mathrm{m} \mathrm{m}^{-1}$ salinity had the highest (Figure 3). Therefore, salinity had an increasing effect on catalase activity, so that the activity of this enzyme rised with the increase in salinity level. Catalase is a enzyme that plays a important role in responding to abiotic stresses, such as salinity (Shalini and Duey, 2003; Ahmadi and Souri, 2019). Simova-Stoilova et al. (2010) found enlarged activity of catalase in wheat plants exposed to drought stress. In addition, the comparison of the means for the effect of SA and P4 indicated that their simultaneous application resulted in the highest level of catalase activity. The control plants, not treated with the hormones, also exhibited the lowest level of this enzyme activity (Figure 4). SA activates many protective enzymes, such as catalase. Antioxidant enzymes are involved in detoxifying reactive oxygen species (ROS). The antioxidant enzymatic system of plants is composed of several enzymes with low molecular weight, but their concentrations vary at the cell level in different plants (Dixit et al., 2001). Drought prolongation reduced catalase activity and amplified lipid peroxidation in the shoots of bentgrass (DaCosta and Huang, 2007). Fu and Huang (2001) found that as drought was prolonged in the soil surface, superoxide dismutase activity increased in the leaves of Kentucky bluegrass and tall fescue, but catalase activity was constant. However, when the drought stress prolonged further and the soil dried completely, declines were observed in the activity of both enzymes. 


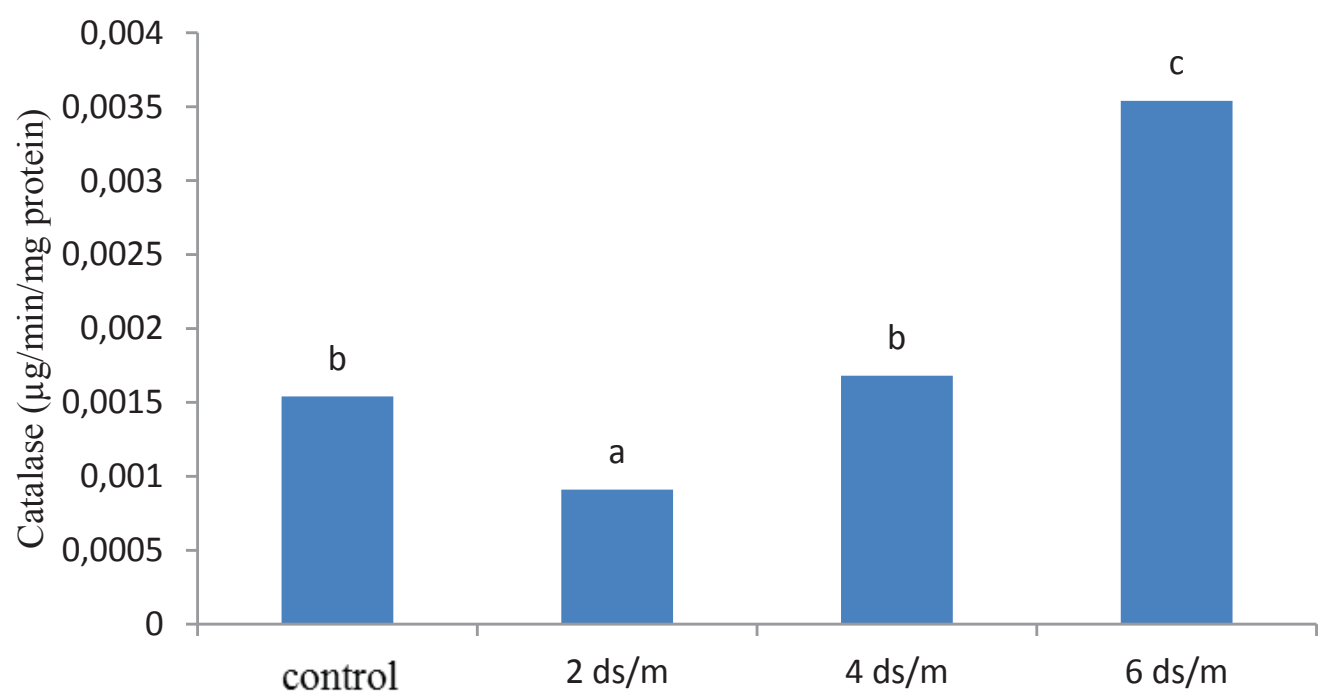

Figure 3. The effect of different levels of salinity stress on catalase of Kentucky bluegrass.

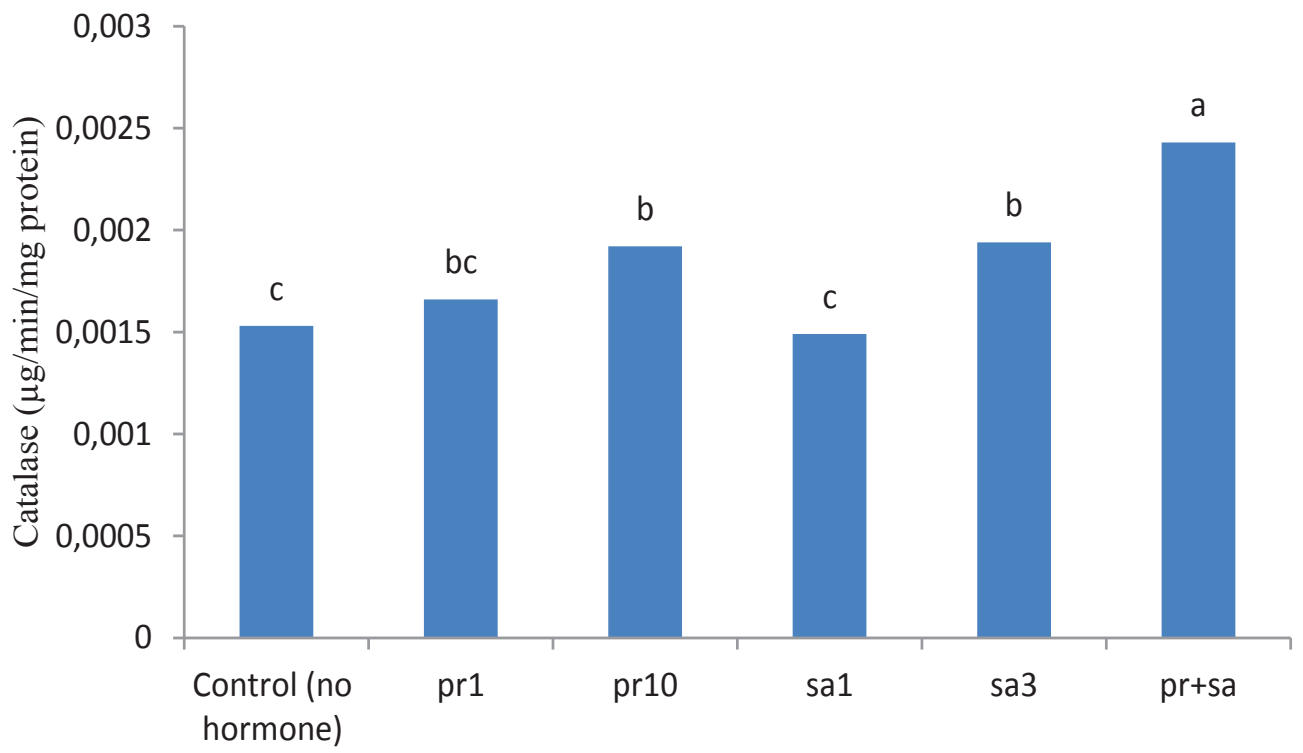

Figure 4. The impact of different concentration of progesterone and salicylic acid on catalase of Kentucky bluegrass.

Photosynthetic pigments. As the results of ANOVA indicated, the simple impact of salinity stress and the interaction of salinity stress and hormones brought about significant differences in chlorophyll $a$, chlorophyll $b$, chlorophyll $a+b$, and carotenoid content of the leaves. Total chlorophyll was also influenced significantly by the hormones (Table 3). The control salinity stress treated with SA + P4 showed the highest carotenoid content and the plants exposed to $6 \mathrm{dS} \mathrm{m}^{-1}$ salinity but not treated with the hormones exhibited the lowest one. The interaction of no stress and $3 \mathrm{mM}$ SA resulted in the highest 
mean chlorophyll $a$ and the interaction of $6 \mathrm{dS} \mathrm{m}^{-1}$ salinity and the control treatment resulted in the lowest one. The plants with treatment $2 \mathrm{dS} \mathrm{m}^{-1}$ salinity and $10 \mathrm{mg} \mathrm{L}^{-1} \mathrm{P} 4$ produced the highest amount of chlorphyll $b$ and the plants exposed to $4 \mathrm{dS} \mathrm{m}^{-1}$ salinity but not hormones produced the lowest amount. The maximum and minimum total chlorophyll were related to the interaction of $2 \mathrm{dS} \mathrm{m}^{-1}$ salinity and $10 \mathrm{mg} \mathrm{L}^{-1} \mathrm{P} 4$ and the interaction of $6 \mathrm{dS} \mathrm{m}^{-1}$ salinity and no hormone application, respectively (Table 4). Slattery et al. (2017) reported that an increase in salinity and drought stress decreased leaf chlorophyll $a$ but increased chlorphyll $a / b$; this increase would darken leaf chlorophyll and increase the chlorophyllmeter reading. The loss of chlorophyll under salt stress has been ascribed to the increase in the chlorophyllase activity.

Nonetheless, in addition to the effect of chlorophyllase on chlorophyll decompsition, some researchers have assumed roles for peroxidase and phenol compounds in this respect (Ashraf et al., 2010). In these conditions, no decrease is observed in photosynthesis, partially due to the loss of chlorophyll concentration by its decomposition. Consistent with our findings, various studies have revealed that abiotic stresses, such as drought and salinity, decrease various chlorophylls Idrees et al. (2010). SA application to leaf parts of canola (Brassica napus) increased chlorophyll content (Ghai et al., 2002). In this study, salinity stress exposure reduced chlorophyll $a, b$, and $a+b$ in the plants, but the application of SA and P4 created plants with higher levels of chlorophyll $a, b$, and $a+$ $b$.The difference in the extent of this impact may reflect the effect of different rates of SA on grass, which is in agreement with the reports of Hayat et al. (2010).There are reports as to the increase (Aftab et al., 2010) and decrease (Taïbi et al., 2016) in carotenoid content under salinity stress. Also, it appears that the application of plant hormones, e.g. SA and $\mathrm{P} 4$, increases all plant pigments in both stressful and normal conditions (Erdal et al., 2012). Taïbi et al. (2016) found that salinity decreased carotenoid by $20 \%$. Chaparzadeh and Hosseinzad-Behboud (2015) found that SA used in saline condition improved leaf carotenoid. Declines were reported by ElTayeb (2006) in chlorophyll $a, b$, and $a+b$.

\section{CONCLUSIONS}

The results showed that salinity stress applied in the first weeks did not influence grass quality and leaf firing percentage significantly, but as the stress was prolonged, its impacts on the quality and leaf firing emerged. Salinity stress of $6 \mathrm{dS} \mathrm{m}^{-1}$ diminished lawn quality by $60 \%$ in the last week versus the first week. Also, with the increase in salinity stress, the grass quality decreased severely so that the quality was the poorest at salinity level of $6 \mathrm{dS} \mathrm{m}^{-1}$. Salinity treatments increased leaf catalase activity. Also, SA and P4 improve salinity tolerance of Poa grass by increasing photosynthetic pigments in these conditions. It was revealed that SA and P4 had different impacts, but their simultaneous application performed the best for most recorded physiological traits, which can be attributed to the simultaneous supply of elements related to these two hormones and the escalation of plant efficiency in the use of these two hormones.

Conflict of interest: The authors declare that there is no conflict of interest. 


\section{BIBLIOGRAPHIC REFERENCES}

Adavi, Z.; Mobli, M.; Razmjo, K.H. (2006). Effects of salinity level of irrigation water on African lawn cultivars (Cynodon dactylon) under soil salinity in Esfahan. Natural Resources and Agricultural Technology. 10: 179-190.

Aebi, H. (1984). Catalase in vitro. Methods in Enzymology. 105:121-126. doi: 10.1016/ s0076-6879(84)05016-3

Aftab, T.; Khan, M.M.A.; Idrees, M.; Naeem, M.; Singh, M.; Ram, M. (2010). Stimulation of crop productivity, photosynthesis and artemisinin production in Artemisia annua L. by triacontanol and gibberellic acidapplication. Journal of Plant Interactions. 5: 273-281. doi:10.1080/17429141003647137

Agarwal, S.; Sairam, R. K.; Srivastava G. C.; Meena, R.C. (2005). Changes in antioxidant enzymes activity and oxidative stress by abscisic acid and salicylic acid in wheat genotypes. Biologia Plantarum. 49: 541-550. doi: 10.1007/s10535005-0048-z

Ahmadi, M.; Souri, M. K. (2020). Growth characteristics and fruit quality of chili pepper under higher electrical conductivity of nutrient solution induced by various salts. AGRIVITA, Journal of Agricultural Science. 42(1): 143-152. doi: 10.17503/agrivita.v42i1.2225

Ahmadi, M.; Souri, M. K. (2019). Nutrient uptake, proline content and antioxidant enzymes activity of pepper (Capsicum annuum L.) under higher electrical conductivity of nutrient solution created by nitrate or chloride salts of potassium and calcium. Acta Scientiarum Polonorum, Hortorum Cultus. 18(5): 113-122. doi: 10.24326/asphc.2019.5.11

Ahmadi, M.; Souri, M. K. (2018). Growth and mineral elements of coriander (Corianderum sativum L.) plants under mild salinity with different salts. Acta Physiologia Plantarum. 40: 94-99. doi: 10.1007/s11738-018-2773-x
Alshammary, S. F.; Qian, Y. L.; Wallner, S. J. (2004). Growth response of four turfgrass species to salinity. Agricultural Water Management. 66(2): 97-111. doi: 10.1016/j.agwat.2003.11.002

Arghavani, M.; Savadkoohi, S.; Mortazavi, N. (2017). Salinity tolerance of Kentucky Bluegrass as affected by salicylic acid. Journal of Ornamental Plants. 7(4): 237-245.

Arnof, S. (1946). Photochemical reduction of chloroplast grana. Plant Physiology. 21(4):393409. doi: 10.1104/pp.21.4.393

Ashraf, M.; Akram, N. A.; Arteca,R. N.; Foolad, M. R. (2010). The physiological, biochemical and molecular roles of brassinosteroids and salicylic acid in plant processes and salt tolerance. Critical Reviews in Plant Sciences. 29: 162-190. doi: 10.1080/07352689.2010.483580

Bates, L. S.; Waldren, R.P.; Teare, I. D. (1973). Rapid determination of free proline for water stress studies. Plant and Soil. 39(1): 205-207. doi: $10.1007 / \mathrm{bf00018060}$

Bradford, M. M. (1976). A rapid and sensitive method for the quantitation of microgram quantities of protein utilizing the principle of protein-dye binding. Analytical Biochemistry. 72: 248- 254. doi: 10.1016/0003-2697(76)90527-3

Chaparzadeh, N.; Hosseinzad-Behboud, E. (2015). Evidence for enhancement of salinity induced oxidative damages by salicylic acid in radish (Raphanus sativus L.). Journal of Plant Physiology and Breeding, 5(1): 23-33.

DaCosta, M.; Huang, B. (2007). Changes in antioxidant enzyme activities and lipid peroxidation for bentgrass species in responses to drought stress. Journal of the American Society for Horticultural Science. 132: 319-326. doi: 10.21273/jashs.132.3.319

Demiral, T.; Türkan, I. (2006). Exogenous glycinebetaine affects growth and proline accumulation and retards senescence in two rice cultivars under $\mathrm{NaCl}$ stress. Environmental and Experimental Botany. 56: 72-79. doi: 10.1016/j. envexpbot.2005.01.005 
Dixit, V.; Pandey, V.; Shyam, R. (2001). Differential antioxidative responses to heavy metal in roots and leaves of pea (Pisum sativum L. CV. Azad). Journal of Experimental Botany. 52:(358): 11011109. doi: 10.1093/jexbot/52.358.1101

El-Tayeb, M. A.; El-Enany, A. E.; Ahmed, N. L. (2006). Salicylic acid-induced adaptive response to copper stress in sunflower (Helianthus annuus L.). Plant Growth Regulation. 50: 191-199. doi: 10.1007/s10725-006-9118-2

Erdal, S.; Genisel, M.; Turk, H.; Gorcek, Z. (2012). Effects of progesterone application on antioxidant enzyme activities and $\mathrm{K}+/$ $\mathrm{Na}+$ ratio in bean seeds exposed to salt stress. Toxicology and Industrial Health. 28. 942-6. 10.1177/0748233711430975.

Erdal, S.; Dumlupinar, R. (2011). Mammalian sex hormones stimulate antioxidant system and enhance growth of chickpea plants. Acta Physiologiae Plantarum. 33(3):1011-1017. doi: 10.1007/s11738-010-0634-3.

$\mathrm{Fu}$, J.; Huang, B. (2001). Involvement of antioxidants and lipid peroxidation in the adaptation of two cool-seasion grasses to localized drought stress. Environmental and Experimental Botany. 45: 105-114. doi: 10.1016/S0098-8472(00)00084-8.

Genisel, M.; Turk, H.; Erdal, S. (2013). Exogenous progesterone application protects chickpea seedlings against chilling-induced oxidative stress. Acta Physiologiae Plantarum. 35: 241251. doi: 10.1007/s11738-012-1070-3.

Ghai, N.; Setia, R. C.; Setia, N. (2002). Effects of paclobutrazol and salicylic acid on chlorophyll content, hill activity and yield components in Brassica napus L. (cv. GSL 1). Phytomorphology. 52: 83-87.

Grieve, C.; Grattan, S. (1983). Rapid assay for determination of water soluble quaternary ammonium compounds. Plant and Soil. 70: 303307. doi: 10.1007/bf02374789
Hayat, Q.; Hayat, S. Ifran, M.; Ahmad, A. (2010). Effect of exogenous salicylic acid under changing environment: a review. Environmental and Experimental Botany. 68: 14-25. doi: 10.1016/j. envexpbot.2009.08.005

Idrees, M.; Khan, M. M. A.; Aftab, T.; Naeem, M.; Hashmi, N. (2010). Salicylic acid induced physiological and biochemical changes in lemongrass varieties under water stress. Journal of Plant Interactions. 5: 293- 303. doi: 10.1080/17429145.2010.508566

Koch, M. J.; Huang, B. R.; Bonos, S. A. (2011). Salinity tolerance of Kentuckybluegrass cultivarsand selections using an overhead irrigated screening technique. Crop Science. 51: 2846-2857. doi: 10.2135/cropsci2011.03.0174

Ma, X. L.; Wang Y. J.; Xie S. L.;Wang C.; Wang W. 2007. Glycine betaine application ameliorates negative effects of drought stress in tobacco. Russian Journal of Plant Physiology. 54: 472-479. doi: 10.1134/S1021443707040061

Manna, A.; Mimouni, H.; Wasti, S.; Gharbi, E.; Aschi-Smiti, S.; Faurobert, M.; Ben Ahmad, H. (2013) Comparative proteomic analysis of tomato (Solanum lycopersicum) leaves under salinity stress. Plant Omics Journal. 6: 268-277.

Metwally, M. A.; Awad, A.; Abou-Leila, B.; Tayeb, T.; Habba, I. (2015). Studies on the effect of gamma, laser irradiation and progesterone treatments on gerbera leaves. European Biophysics Journal. 21: 3(6): 43-50. doi: 10.11648/j.ejb.20150306.11

Moghadamyar, M.; Kazemsouri, M.; Motalebi, E.; Reza Rouzban, M. (2019). Effects of foliar application of salicylic acid on growth characteristics of lolium grass under salt stress condition. Journal of Environmental Science and Technology. 20(4): 142-152.

Padash, A.; Ghanbari A.; Sirousmehr A. R.; Asgharipour M. R. (2018). Effect of salicylic acid on basil resistance against lead. Journal of Plant Research. 31(1): 118-129.

Parvaiz, A.; Satyawati, S. (2008). Salt stress and phytobiochemical responses of plants. Plant, Soil and Environment. 54: 89-99. 
Pettigrew, W. T. (2004). Physiological consequences of moisture deficit stress in cotton. Crop Science. 44: 1265-1272. doi: 10.2135/cropsci2004.1265

Rojek, J.; Pawełko, L.; Kapusta, M.; Naczk, A.; Bohdanowicz, J. (2015). Exogenous steroid hormones stimulate full development of autonomous endosperm in Arabidopsis thaliana. Acta Societatis Botanicorum Poloniae. 84(2):287-301. doi: 10.5586/asbp.2015.022

Shalini, V.; Duey, R. S. (2003). Lead toxicity induces lipid peroxidation and alters the activities of antioxidant enzymes in growing rice plants. Plant Science. 164: 1645-1655. doi: 10.1016/ s0168-9452(03)00022-0

Slattery, R.; VanLoocke, A.; Bernacchi, C.; Zhu, X.; Ort D. (2017). Photosynthesis, light use efficiency, and yield of reduced-chlorophyll soybean mutants in field conditions. Frontiers in Plant Science. 8: 549. doi: 10.3389/ fpls.2017.00549

Simova-Stoilova, L.; Vaseva, I.; Grigorova, B.; Demirevska, K.; Feller, U. (2010). Proteolytic activity and cysteine protease expression in wheat leaves under severe soil drought and recovery. Plant Physiology and Biochemistry. 48: 200-206. doi: 10.1016/j.plaphy.2009.11.003

Soliman, W. S.; Sugiyama, S.; Abbas, A. M. (2018). Contribution of avoidance and tolerance strategies towards salinity stress resistance in eight C3 turfgrass species. Horticulture, Environment, and Biotechnology. 59(1): 29-36. doi: 10.1007/s13580-018-0004-4

Souri, M. K.; Hatamian, M. (2019). Aminochelates in plant nutrition; a review. Journal of Plant Nutrition. 42 (1): 67-78. doi: 10.1080/01904167.2018.1549671

Souri, M. K.; Neumann, G. (2018). Indications for passive rather than active release of natural nitrification inhibitors in Brachiaria humidicola root exudates. Journal of Plant Nutrition. 41(4): 477-486. doi: 10.1080/01904167.2017.1385809
Souri, M. K.; Tohidloo, G. (2019). Effectiveness of different methods of salicylic acid application on growth characteristics of tomato seedlings under salinity. Chemical and Biological Technologies in Agriculture. 6(1): 26. doi: 10.1186/s40538-019-0169-9

Taïbi, K.; Taïbi, F.; Abderrahim, L. A.; Ennajahb, A.; Belkhodja, M.; MiguelMulet, J. (2016). Effect of salt stress on growth, chlorophyll content, lipid peroxidation and antioxidant defence systems in Phaseolus vulgaris L. South African Journal of Botany. 105: 306-312. doi: 10.1016/j. sajb.2016.03.011

Tajmirriahi, R.; Etemadi, N. A.; Mortezanezhad, F.; Sadeghi, A. (2015). Evaluation of salinity tolerance of native exotic wheat grass species. Journal of Plant Physiology. 7: 93-104.

Waseem, M.; Athar, H. U. R.; Ashraf, M. (2006). Effect of salicylic acid applied through rooting medium on drought tolerance of wheat. Pakistan Journal of Botany. 38(4): 1127-1136.

Xue, R. L.; Wang, S. Q.; Xu, H. L.; Zhang, P. J., Li, H.; Zhao, H. J. (2017). Progesterone increases photochemical efficiency of photosystem II in wheat under heat stress by facilitating D1 protein phosphorylation. Photosynthetica. 55(4): 664670. doi: 10.1007/s11099-016-0681-0

Yang, Z.; Chang, Z.; Sun, L.; Yu, J.; Huang, B. (2014). Physiological and metabolic effects of 5-aminolevulinic acid for mitigating salinity stress in creeping bentgrass. PLOS ONE. 9(12): 1-25. doi: 10.1371/journal.pone.0116283

Yang, Z.; Yu, J.; Merewitz, E.; Huang, B. (2012). Differential effects of abscisic acid and glycine betaine on physiological responses to drought and salinity stress for two perennial grass species. Journal of the American Society for Horticultural Science. 137(2): 96-106. doi: 10.21273/jashs.137.2.96

Zhang, X. (2016). Salicylic acid, auxin and tryptophan impact on salt tolerance of creeping bentgrass. Received from https://scisoc. confex.com/scisoc/2016am/webprogram/ Paper100655.html 